\title{
Sandy Soil Improvement Using MICP-Based Urease Enzymatic Acceleration Method Monitored by Real-Time System
}

\author{
Janjit Iamchaturapatr, ${ }^{1}$ Keeratikan Piriyakul (i), ${ }^{1}$ Thanate Ketklin, ${ }^{2}$ Gemmina Di Emidio, ${ }^{3}$ \\ and Aruz Petcherdchoo (iD) ${ }^{4}$ \\ ${ }^{1}$ Center of Excellence in Structural Dynamics and Urban Management, \\ Department of Civil and Environmental Engineering Technology, College of Industrial Technology, \\ King Mongkut's University of Technology North Bangkok, Bangkok, Thailand \\ ${ }^{2}$ Former Graduate Student in Construction Engineering Technology, \\ Department of Civil and Environmental Engineering Technology, College of Industrial Technology, \\ King Mongkut's University of Technology North Bangkok, Bangkok, Thailand \\ ${ }^{3}$ Laboratory of Geotechnics, Department of Civil Engineering, Faculty of Engineering and Architecture, Ghent University, \\ Ghent, Belgium \\ ${ }^{4}$ Department of Civil Engineering, Faculty of Engineering, King Mongkut's University of Technology North Bangkok, \\ Bangkok, Thailand
}

Correspondence should be addressed to Keeratikan Piriyakul; keeratikan.p@cit.kmutnb.ac.th

Received 20 May 2021; Revised 31 August 2021; Accepted 14 September 2021; Published 29 September 2021

Academic Editor: Francesco Colangelo

Copyright (c) 2021 Janjit Iamchaturapatr et al. This is an open access article distributed under the Creative Commons Attribution License, which permits unrestricted use, distribution, and reproduction in any medium, provided the original work is properly cited.

This paper aims at monitoring the improvement of sandy soil properties with biocementation through the microbially induced calcite precipitation (MICP) method with reaction accelerations by self-developed soybean urease enzymes. In this study, the concentration of calcium ions $\left(\mathrm{Ca}^{2+}\right.$ ions as $\left.\mathrm{CaCl}_{2}\right)$ is varied at $50,100,250$, and $500 \mathrm{mM}$ to determine an optimum shear strength. The self-developed soybean urease enzymes of $20 \%$ by volume (v/v) are used to accelerate the MICP reaction to finish within 7 days. Based on real-time monitoring bender element system and direct shear tests, the optimum $\mathrm{Ca}^{2+}$ concentration is found as $250 \mathrm{mM}$. However, a detrimental effect occurs in case of high concentration of $\mathrm{Ca}^{2+}$ as $\mathrm{CaCl}_{2}(500 \mathrm{mM})$ because of solution acidification from high $\mathrm{Cl}^{-}$concentration. This condition lowers $\mathrm{CaCO}_{3}$ precipitation causing the reduction of biocementation process. At equivalent shear modulus, the biocementation time of MICP-based sand with acceleration by urease enzymes is about 10 times faster than that without. Using spectrophotometer and $\mathrm{pH}$ meter, the ammonification rate and the solution $\mathrm{pH}$ of biocemented sand with acceleration by urease enzymes for 3 days are found relatively higher than those without urease enzymes for 40 days. The analyses by scanning electron microscopy (SEM) and X-ray diffraction (XRD) confirm not only the occurrence of $\mathrm{CaCO}_{3}$ binding sand particles together but also the improvement of physical strengths of sandy soil samples with the MICP-based urease enzymatic acceleration method. These results introduce an option to accelerate biocemented sandy soil improvement.

\section{Introduction}

Soil improvement industry was found to cost up to 6 billion dollars per year, also leading up to 40,000 projects per year worldwide [1]. The need of ground improvement has been growing up; hence, many improvement methods have also been invented, such as biomediated soil improvement method. This method showed greater potential in terms of performance and environmental sustainability [2], which has been an important in construction [3-5]. In addition, not only biologically controlled and induced mechanisms were important, but also other encountered in situ factors during microbially induced calcite precipitation (MICP) should be taken into account. For soil improvement by MICP, there were three main tasks to be carried out [6]: (1) understanding the fundamentals of the microbial, chemical, and flow processes, (2) connecting ecological, environmental, and carbon footprint benefits for engineering 
performance enhancement, and (3) retaining ecological balance and environmental friendliness to avoid long-term deterioration as well as lowering the energy demand. A review [7] indicated that the uniform treatment of a large zone of soil required advanced system modeling, and the development of real-time field- or practical-scale monitoring techniques to ensure spatially uniform treatment was necessary. Many researchers have conducted several specific research studies related to MICP as follows.

Related to the properties of MICP-treated sandy soil, Ivanov and $\mathrm{Chu}[8]$ stated that, through microbial means, bioclogging reduced the porosity and hydraulic conductivity of soil by producing pore-filling materials, whereas biocementation increased the shear strength of soil by generating in situ particle-binding materials. Later, a group of researchers [9] monitored a biogrouting process based on a large-scale experiment equipped with in situ geophysical measurements in combination with the unconfined compressive strength test. Their study indicated that the stiffness of soil significantly increased after one day of treatment, and the increase could be quantified as a function of the injected volume of grouting agents and the distance from the injection points. Lee [10] used a species of Bacillus group, B. megaterium, to trigger calcite precipitation. At various soil densities and treatment conditions, the robustness of MICP treatment on sand was similar to that on tropically residual soil. The shear strength of treated residual soil was improved, and the saturated hydraulic conductivity of the treated residual soil was reduced. Moreover, the particle-particle contacts, porosity, and pore spaces between soil particles were found to influence the effectiveness of biocementation and bioclogging in residual soil. Later, a research [11] performed undrained simple shear testing of fine sand with varying amounts of MICP-treated silt to a moderate level of cementation to increase the shear wave (S-wave) velocity of 300 to $400 \mathrm{~m} \mathrm{~s}^{-1}$. Apparently, MICP increased the shear strength of the silty sand as well as clean poorly-grade sand. Li [12] studied the optimization of biocementation in sand, and the feasibility of using biocement to improve the mechanical properties of clayey soil. They carried out element tests using small cylindrical samples, and model tests using soil up to one cubic meter. It was found that urease producing bacteria (UPB) with low activity were effective for both small samples and relatively large samples in the model tests. Moreover, the development of strength through biotreatment was largely relevant to the increase in cohesion due to biocementation. Later, a study [13] investigated the particle breakage and the compressibility behavior of MICP-treated sands using oedometric compression tests. The acid washing technique was used to obtain the calcium carbonate $\left(\mathrm{CaCO}_{3}\right)$ content and facilitated the quantification of particle breakage by measuring the particle size distribution (PSD). With a large $\mathrm{CaCO}_{3}$ content, the compressibility was lower for specimens. Moreover, the MICP treatment was effectively able to restrain particle breakage for a given applied stress or input work.

Considering urease dosage and activity in sand, Stabnikov et al. [14] isolated halotolerant and alkaliphilic strains (Bacillus sp. VS1 and VUK5) of urease-producing bacteria for soil biocementation from either sandy soil or high salinity water in different climate zones to ensure the stability of urease activity in biocement. Based on the unconfined compressive strengths for biocemented dry sand samples after six batch treatments, it was found that halotolerant, alkaliphilic, urease-producing bacteria isolated from different climate zones could be used for soil biocementation. Later, a research [15] examined the effect of urease (UR) dosages on the strength development of sandy soil in biocemented sand reactor (BSR). Apparently, UR increased solution $\mathrm{pH}$, and the highest solution $\mathrm{pH}$ during the treatment was found as 20\% UR providing the highest shear strength. A study [16] proposed a novel approach for cementing sandy soils in marine environments by modifying MICP technique, based on dissolving calcium ions $\left(\mathrm{Ca}^{2+}\right)$ in seawater as the sole source for calcite formation. This led to an unconfined compressive strength of up to $300 \mathrm{kPa}$, which was about two times higher than the strength of the MICP treatment using highly concentrated calcium and urea solutions (with the same amount of crystals produced). A group of researchers [17] optimally determined the amount of urea and calcium chloride $\left(\mathrm{CaCl}_{2}\right)$ on the biocalcification process. The methodology first used test-tube experiments to examine the amount of precipitated $\mathrm{CaCO}_{3}$, and the X-ray diffraction (XRD) to verify the existence of $\mathrm{CaCO}_{3}$. Then, it was applied to sandy soil for evaluating its strengthening effects using unconfined compressive strength tests. Apparently, the activity of urease might be inhibited by $\mathrm{CaCO}_{3}$ precipitation, urea- $\mathrm{CaCl}_{2}$ concentration increase, and sandy soil improvement due to the methodology effectiveness. A study [18] found that the injection process was better than the mixing-precipitation process in terms of the compressive strength of biosandstones caused by the particle size and morphology of composite cement. Moreover, the molar ratio of $\mathrm{K}_{2} \mathrm{HPO}_{4} \cdot 3 \mathrm{H}_{2} \mathrm{O}$ to urea was the best at 2 to 1 for the carbonate-mineralized bacteria (Sporosarcina pasteurii, 2L) CJ2 formulation. Cui et al. [19] proposed a high efficiency method for enzyme-induced carbonate precipitation (EICP) by adopting a one-phase injection of low $\mathrm{pH}$ solution strategy, which was simpler and more efficient due to less number of injections. It was observed that their method significantly improved the calcium conversion efficiency and the uniformity of $\mathrm{CaCO}_{3}$ distribution in the sand samples, as compared with the conventional two-phase EICP method. Moreover, the unconfined compressive strength of sand treated by their method was much higher. A group of researchers [20] studied the effect of stabilization of the siliceous, silty, and calcareous sandy soils via biocementation process using $S$. pasteurii bacteria. The results indicated that the times of solution addition remarkably influenced the physical and mechanical properties of sandy soils. Moreover, the precipitation of calcite from the bacterial activity caused cohesion of soil grains, increasing the resistance of soil deterioration. In addition, the high content of the precipitated calcium carbonate increased the shear strength and the unconfined compressive strength, while it decreased the permeability of soil.

With applications of shear wave analyzes to sandy soil improvement, Duraisamy and Airey [21] determined the performance of small-scale cemented soil columns by mixing sandy soil with cement bacterially mediated as 
B. megaterium. The unconfined compressive strength (UCS) and triaxial tests were used to observe the effects of biocementation, while bender elements mounted in a triaxial cell were used to monitor the shear wave velocity during curing and shearing. The study revealed that for a given amount of cement, the bio-cemented samples provided higher resistances than gypsum. With less than $4 \%$ of calcite, the mixing process provided homogeneous biocemented samples with higher strength and stiffness than the commonly used technique of flushing or injection. Ma et al. [22] introduced bentonite in MICP grouting to effectively stabilize coarse sand. Various concentrations $\left(0\right.$ to $\left.80 \mathrm{~g} \mathrm{~L}^{-1}\right)$ of bentonite were added to bacterial suspensions (BSs) by magnetically stirring to form bacterial-bentonite suspensions (BBSs). Then, coarse sand specimens were treated with BBSs and cementation solutions (CSs) using different cementation levels. Apparently, the bentonite increased the volume fractions of the precipitates consisting of $\mathrm{CaCO}_{3}$ and bentonite. Using lower concentration (e.g., $20 \mathrm{~g} \mathrm{~L}^{-1}$ ) of bentonite, the active precipitates increased, and the unconfined compressive strength (UCS) was substantially improved. However, negative effects were observed for a high concentration of bentonite.

Taking advantage of microscale imaging analysis on sandy soil, a group of researchers [23] proposed a method to produce soluble calcium using calcium rich calcareous sand in the MICP process to improve the properties of soil. The scanning electron microscopy (SEM) and X-ray diffraction (XRD) analyses revealed that the aragonite crystals with acicular mineral morphology were formed when using the soluble calcium, whereas the calcite crystals with a rhombohedral mineral morphology were formed when using $\mathrm{CaCl}_{2}$. Choi et al. [24] used $\mathrm{CaCO}_{3}$ produced from MICP to control the properties of biocemented soil. Considering the $\mathrm{CaCO}_{3}$ content from six different experiments, they found that the titration and the inductively coupled plasma (ICP) methods led to the lowest $\mathrm{CaCO}_{3}$ content, while the washing method led to the highest content. However, the other methods, i.e., XRD-TOPAS, thermogravimetric analysis (TGA), ASTM D4373-14, produced values falling in between, and the measured values among them were slightly small. Cheng et al. [25] proposed a novel experimental approach using in situ microbially induced $\mathrm{Ca}^{2+}$-alginate polymeric sealant for seepage control in porous materials. The SEM images showed that a film-type coating was formed around sand particles with embedded spherical round crystals. Later, a research [26] investigated the composition, shape, and bonding characteristics of physical assemblies of microbial cemented sand (MCS) using XRD, X-ray computed tomography (XCT), and SEM. The study proposed precision DEM modeling of MCS, mainly composed of irregular particle modeling and a mesoparameter calibration algorithm for the thermal cracking analysis under various strains (i.e., $1.0 \%$ to $3.0 \%$ ). Apparently, three kinds of bonding (sand-calcite, calcite-calcite, and sand-sand) existed in the MCS material. Moreover, the temperature influenced the damage of MCS material with increasing strain, and the length of thermal cracks in the transverse direction increased throughout the heating process. A group of researchers [27] proposed an MICP technique to reinforce sands for mitigating natural hazards caused by the wind erosion using a series of small-scale laboratory experiments with different treatment cycles. The results showed that the bulk density of treated sand was slightly increased with the number of MICP treatment cycles. In addition, the wind erosion rate of treated sands was significantly decreased. Moreover, the UCC strength was increased (maximum to $4 \mathrm{MPa}$ ) with the number of treatment cycles, which mainly contributed to the bonding effect from the microbial-induced $\mathrm{CaCO}_{3}$ crystals among sand particles based on SEM analyses. Wang et al. [28] investigated the thermal conductivity of MICP-treated dry sands with different treatment cycles in laboratory. The results revealed that thermal conductivity of treated sands was much higher than that of untreated sand under dry conditions, and it also increased with treatment cycles. Based on SEM, MICP-induced $\mathrm{CaCO}_{3}$ crystals were found around sand particles, so-called thermal bridge, which provided highly effective heat transfer path. It was also concluded that the MICP technique could significantly improve the thermal conductivity of sands and the overall heat transfer efficiency. Yang et al. [29] considered the effects of different sand particle sizes on the engineering characteristics of biotreated sand column, using intermittent injection method to develop biotreated sand columns. In case of low concentration of bacterial suspension and cementation reagent, the improved mechanical properties of the biotreated column by increasing the particle size were improved, and $\mathrm{CaCO}_{3}$ and UCS also increased. Furthermore, the increase of sand particle size was beneficial to the uniformity of spatial distribution of $\mathrm{CaCO}_{3}$ in the biotreated column. The SEM results confirmed that the size and uniformity of calcite crystals on the surface of sand particles were related to the concentration of cementation solution.

According to the aforementioned literature reviews, there are two issues to be further addressed. First, a urease enzymatic acceleration method to attain an optimum concentration of $\mathrm{Ca}^{2+}$ ions (as $\mathrm{CaCl}_{2}$ ) in sandy soil biocementation process through MICP method is necessary in practice. Second, a real-time monitoring system is required in order to capture the saturation of continuous reactions of accelerated MICP-based sandy soil under wet condition throughout experiments. To merge these two gaps, this study proposes to vary the concentration of $\mathrm{Ca}^{2+}$ ions as well as utilize urease enzyme to accelerated MICP processes to finish within 7 days. Moreover, various equipment is used, i.e., (1) the bender element tests embedded in the self-developed real-time monitoring system to estimate the shear wave velocity through sand samples, (2) the spectrophotometer and $\mathrm{pH}$ meter to measure ammonification rate and solution $\mathrm{pH}$, respectively, (3) the direct shear tests to determine both cohesion and internal friction angle, and (4) the XRD and SEM tests to confirm $\mathrm{CaCO}_{3}$ binding.

\section{Fundamentals of MICP Process}

There were two main approaches for MICP biocementation of soil, i.e., bioaugmentation and biostimulation [30]. The former relied on the injection of specialized bacterial strains 
with specific metabolic capabilities to complete the biogeochemical process; however, this approach was restricted due to economic and environmental feasibility. The latter relied on the modification of existing environmental conditions (substrates, nutrients, electron acceptors, etc.) to enrich existing microbial communities for native microorganisms with desirable metabolic capabilities to complete the process. Gomez et al. [30] compared a large-scale experiment using a bioaugmentation approach (with S. pasteurii) to a biostimulation approach (with native ureolytic microorganisms) and suggested that the final improvement of biocementation process of the two approaches at the meter scale is similar based on considering shear wave velocity, biogeochemical changes, and posttreatment cone penetration tests. Zeng et al. [31] carried out a field trial to evaluate the potential of MICP through urea hydrolysis for ground stabilization, based on locally enriched bacterial injected bioaugmentation, followed by urea and calcium chloride solution. In situ monitoring results were also analyzed using a two-dimensional (2D) numerical reactive transport model to evaluate the process performance. The combined results of monitoring and numerical modeling demonstrated that treatment was limited to approximately $5 \%$ of the total soil volume. The conversion efficiency was significantly lower than expected, and the substrates spread farther than originally intended, which could be attributed to the heterogeneous soil profile with a large amount of fines, causing preferential flow through the morepermeable layers and possibly hydraulically induced fractures. Fang and Achal [32] attempted to apply the biostimulation approach to develop cement stabilized rammed Earth (CSRE) as sustainable construction material. Their results showed that biostimulation improved the compressive strength but reduced water absorption. The biocementation process was characterized by Fourier transform infrared spectroscopy, X-ray diffraction, and SEM-energy dispersive spectrometer. Further, Illumina MiSeq sequencing was used to investigate changes in bacterial community structures after biostimulation that identified the majority of ureolytic bacteria dominated by phylum Firmicutes and genus Sporosarcina playing role in biocementation.

Considering the bioaugmentation approach, the microbially induced calcite precipitation (MICP) method utilized nonharmful bacteria, which could naturally replicate themselves without soil disturbance using low-energy input. Microbes such as Bacillus sp. and Sporosarcina sp. grow up in media comprising urea and calcium ion. In a specific condition, these microbes induce calcite $\left(\mathrm{CaCO}_{3}\right)$ precipitation, which filled into pores within soil particles and bonded them together $[1,9,33-35]$. This is so-called biocementation process, and it can be used for stabilizing and improving the strength capacity of ground. The biocementation process starts by hydrolyzing $\mathrm{CO}\left(\mathrm{NH}_{2}\right)_{2}$ or $\mathrm{NH}_{2}-\mathrm{CO}-\left(\mathrm{NH}_{2}\right)$ as follows:

$$
\begin{gathered}
\mathrm{CO}\left(\mathrm{NH}_{2}\right)_{2}+\mathrm{H}_{2} \mathrm{O} \longrightarrow \mathrm{NH}_{2} \mathrm{COOH}+\mathrm{NH}_{3} \\
\mathrm{NH}_{2} \mathrm{COOH}+\mathrm{H}_{2} \mathrm{O} \longrightarrow \mathrm{H}_{3}+\mathrm{H}_{2} \mathrm{CO}_{3}
\end{gathered}
$$

The products from (1) and (2), i.e., $\mathrm{NH}_{3}$ and $\mathrm{H}_{2} \mathrm{CO}_{3}$, subsequently equilibrate in water to form $\mathrm{NH}_{4}{ }^{+}$, hydroxide $\left(\mathrm{OH}^{-}\right)$ions, and $\mathrm{CO}_{3}{ }^{2-}$ as

$$
\begin{gathered}
2 \mathrm{NH}_{3}+2 \mathrm{H}_{2} \mathrm{O} \longrightarrow 2 \mathrm{NH}_{4}^{+}+2 \mathrm{OH}^{-} \\
2 \mathrm{OH}^{-}+\mathrm{H}_{2} \mathrm{CO}_{3} \longrightarrow \mathrm{CO}_{3}^{2-}+2 \mathrm{H}_{2} \mathrm{O}
\end{gathered}
$$

In the presence of $\mathrm{Ca}^{2+}$ ions, the formation of $\mathrm{CaCO}_{3}$ crystals can be induced as shown by the following equation:

$$
\mathrm{Ca}^{2+}+\mathrm{CO}_{3}^{2-} \longrightarrow \mathrm{CaCO}_{3}
$$

The precipitation of $\mathrm{CaCO}_{3}$ from equation (4) is shown in Figure 1. This biocementation process can improve the mechanical properties of porous materials $[8,36-39]$. In addition to the biocementation process, Muynck et al. [33] further stated that the biocementation through ureolysis showed many advantages over other generating pathways and had a high potential to build a large quantity of $\mathrm{CO}_{3}^{2-}$ within a short period of time.

\section{Test Materials}

3.1. Sand Samples. Here, a set of sand samples was taken from the northern part of the Chaophraya river in Suphanburi province, which is about $100 \mathrm{~km}$ from Bangkok, Thailand. After stirring in tap water and rinsing with deionized water (DIW) for cleaning, the sand samples were dried in an oven at $103^{\circ} \mathrm{C}$ for 72 hours and cooled down in a desiccator. To obtain a complete set of very fine sand, the sand samples were later sieved through the ASTM sieve number 100 with the opening of $0.149 \mathrm{~mm}$ and retained on the sieve number 200 with the opening of $0.074 \mathrm{~mm}$. Then, the sand samples were again dried with an oven at $103^{\circ} \mathrm{C}$ for 24 hours and kept in plastic bags. The very fine sand samples finally possessed the unit weight of $1470 \mathrm{~kg} \mathrm{~m}^{-3}$, the cohesion of $0.48 \mathrm{Tm}^{-2}$, and the internal friction angle of 23 degree.

3.2. Biocementation Initiative Solution. Basically, the rate of calcite formation in sand relies on the type of microorganisms; therefore, biocemented initiative solution (BIS) can be prepared using both natural and chemical enzyme microbes. These microbes are used to catalyze urea hydrolysis reaction, which induces the precipitation of $\mathrm{CaCO}_{3}$. Due to a plenty of natural ureolytic microorganisms growing in a natural environment, the microbial community is naturally mixed together. To utilize them in this study, urea microorganisms were brought from the natural water in the Chaophraya river, Thailand. By further trial tests, the BIS in biocementation was designed to have $250 \mathrm{mM}$ of urea or $\mathrm{CO}\left(\mathrm{NH}_{2}\right)_{2}, 250 \mathrm{mM}$ of $\mathrm{Ca}^{2+}$ ion as $\mathrm{CaCl}_{2}$ (or $7 \mathrm{~g}$ of $\mathrm{CaCl}_{2}$ in a litre of solution), and $1.5 \mathrm{mM}$ of glucose or $\mathrm{C}_{6} \mathrm{H}_{12} \mathrm{O}_{6}$, unless otherwise specified. Self-developed soybean urease of $20 \%$ by volume was in this study added in the chemically enzymaticinduced biocemented method for accelerating the process of ammonification. In addition, the natural method of decomposing microorganisms was also used for comparison. Furthermore, the concentration of $\mathrm{Ca}^{2+}$ ions in the BIS 


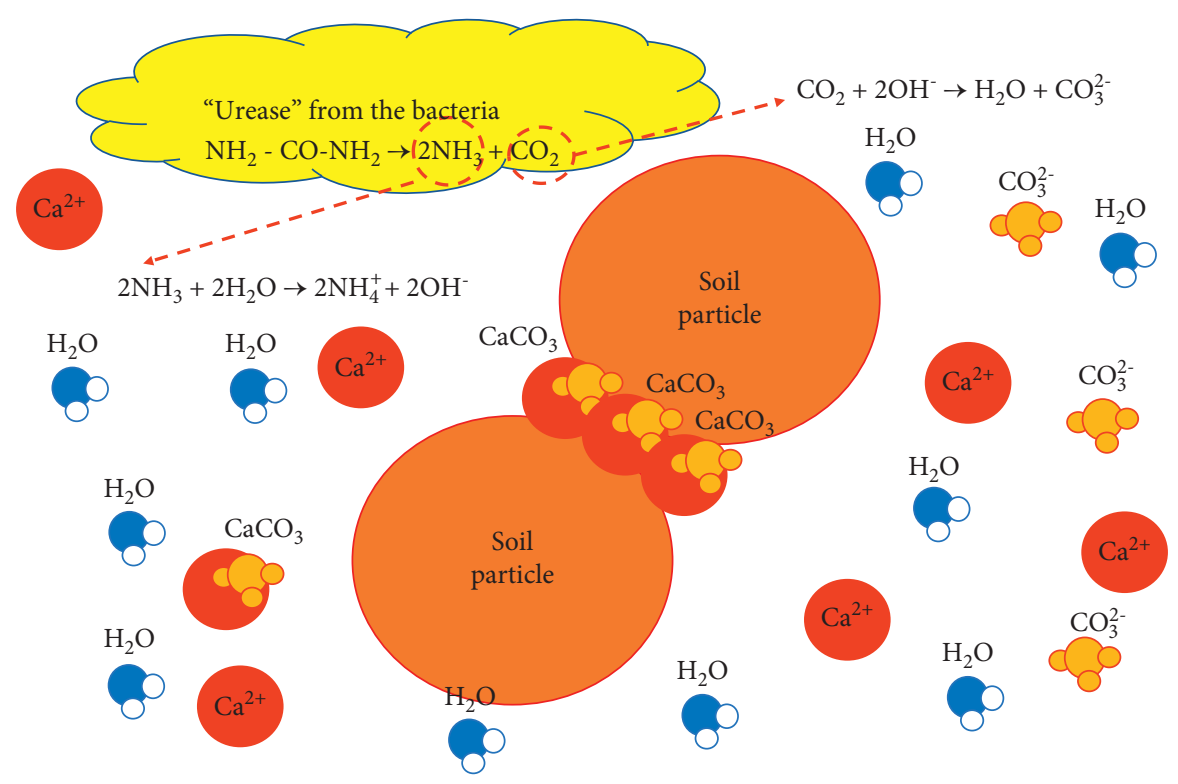

FIGURE 1: Biochemical process via ureolysis inducing $\mathrm{CaCO}_{3}$ precipitation.

was also varied between 50 and $500 \mathrm{mM}$ to observe its effect on strength improvement resulting from the $\mathrm{CaCO}_{3}$ formation in biocemented sand samples.

3.3. Biocemented Sand Reactor. Figure 2 represents a biocement sand reactor (BSR), as a plastic container with $85 \mathrm{~mm}$ in width, $85 \mathrm{~mm}$ in length, and $97.5 \mathrm{~mm}$ in height. In the BSR, the sand samples prepared based on Section 3.1 were placed using a free-drop technique until reaching the total height of $50 \mathrm{~mm}$. Then, the BSR was filled with the BIS, as described in Section 3.2, until reaching the total height of $70 \mathrm{~mm}$. After that, some deionized water (DIW) was added in order to retain the level of the solution, which might be lowered due to water evaporation. All the experiments were performed in an average ambient temperature of $25 \pm 2^{\circ} \mathrm{C}$.

3.4. Bender Element Test and Analytical Procedures. The bender element (BE) test is basically related to the stiffness of soil samples in terms of initial shear modulus $(G)$. Furthermore, the BE test shows many advantages, such as monitoring the change of soil stiffness during kinetic reaction, nondestructive testing (NDT), and spending a short period of testing time. To observe the strength development of sand samples, the bender element test was used to measure the change of S-wave velocity during the enzyme kinetics. The transmitter and receiver of the bender element (BE), adapted from ASTM D8295-19, were each attached at the side of the BSR as shown in Figure 3. The function generator induces shear waves ( $\mathrm{S}$-wave) to the transmitter of $\mathrm{BE}$ in terms of sine wave with the amplitude of $10 \mathrm{~V}$ and the frequency of $12000 \mathrm{~Hz}$. Then, the S-wave penetrates through tested sand samples and reaches the receiver BE. Its travel time through the sand is measured by the oscilloscope. The $\mathrm{S}$-wave velocity can further be calculated $[21,40]$ using the following equation:

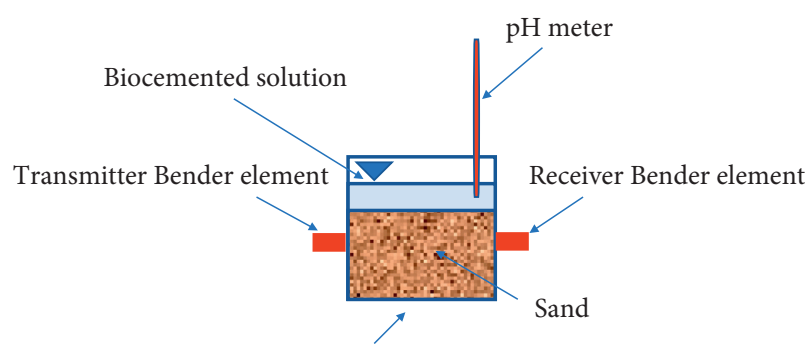

Biocemented Sand Reactor

FIgURE 2: Biocemented sand reactor (BSR).

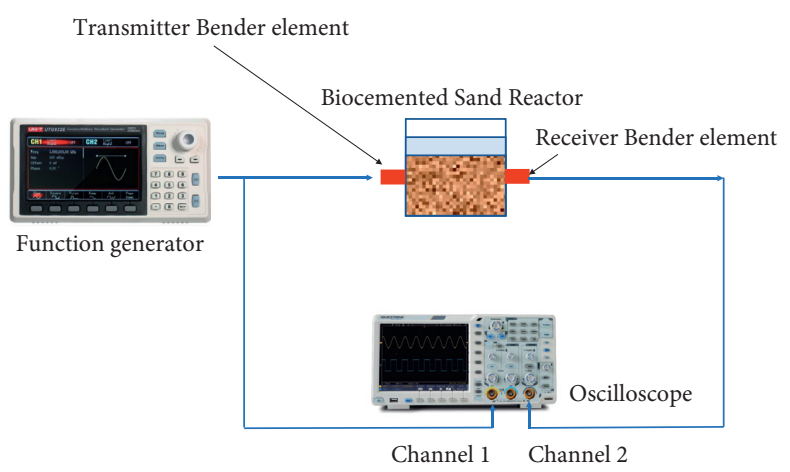

FIgURE 3: Schematic diagram of the bender element (BE) test setup.

$$
V_{s}=\left(L_{i}-L_{b}\right)\left(T_{s}-T_{c}\right)^{-1} \text {, }
$$

where $V_{s}$ is the shear wave velocity $\left(\mathrm{m} \mathrm{s}^{-1}\right), L_{i}$ is the length of tested sand $(\mathrm{m}), L_{b}$ is the total length between the transmitter and the receiver of $\mathrm{BE}(\mathrm{m}), T_{s}$ is a period of measured $S$-wave travel time (s), and $T_{c}$ is the time delay correction (s). The initial shear modulus (G, MPa) of the sand based on the S-wave velocity measurement can be calculated as 
TABLE 1: Constants for calculating S-wave velocity and shear modulus by BE tests.

\begin{tabular}{lcc}
\hline Parameters & Symbol & Value \\
\hline Length of tested sand $(\mathrm{m})$ & $L_{i}$ & 0.085 \\
Total length between the transmitter and the receiver of BE $(\mathrm{m})$ & $L_{b}$ & 0.0055 \\
Time delay correction $(\mathrm{s})$ & $T_{c}$ & $4 \times 10^{-6}$ \\
Sand density $\left(\mathrm{kg} \mathrm{m}^{-3}\right)$ & $\rho$ & 1470 \\
\hline
\end{tabular}

$$
G=(\rho)\left(V_{s}^{2}\right) \times 10^{-6},
$$

where $\rho$ is the sand density $\left(\mathrm{kg} \mathrm{m}^{-3}\right)$, and $V_{s}$ is the shear wave velocity $\left(\mathrm{m} \mathrm{s}^{-1}\right)$. The constants in (5) and (6) are summarized in Table 1.

From the effluent water, the ammonium produced in the form of nitrogen $\left(\mathrm{NH}_{4}{ }^{+}-\mathrm{N}\right)[41]$ and the solution $\mathrm{pH}$ were investigated by the spectrophotometer and $\mathrm{pH}$ meter, respectively. To identify the precipitation of $\mathrm{CaCO}_{3}$, biocemented sand samples were analyzed by SEM and XRD.

\section{Results and Discussion}

4.1. S-Wave through Biocemented Sand. Using the self-developed real-time monitoring bender element system, Figure 4 compares the experimental results for untreated sand (Before) to those for biocemented sand by 50 -day natural method (After). Figure 4(a) shows the S-wave travel time $\left(T_{s}\right)$ through the untreated sand as $600 \mu$ s. Using equation (5) and Table 1 , the S-wave velocity $\left(V_{s}\right)$ can be calculated as $133.4 \mathrm{~m} \mathrm{~s}^{-1}$. Based on equation (6), the initial shear modulus (G) can further be calculated as $26.1 \mathrm{MPa}$. Figure 4(b) shows $T_{s}$ through the biocemented sand by 50 -day natural method as $240 \mu \mathrm{s}$. Using equations (5) and (6) as well as Table $1, V_{s}$ and $G$ can be calculated as $336.9 \mathrm{~m} \mathrm{~s}^{-1}$ and $166.7 \mathrm{MPa}$, respectively. Figure 4(c) indicates the increase of $V_{s}$ and $G$ of the biocemented sand by the 50-day natural method in comparison with the untreated sand.

Figure 5 compares $V_{s}$ and $G$ for biocemented sand between the 50-day natural method and the 5-day chemically enzymatic-induced acceleration method. Apparently, Figures 5(a) and 5(b) show that $T_{s}$ for the natural method is equal to $240 \mu \mathrm{s}$ after 50 days, whereas $T_{s}$ for the acceleration method is equal to $260 \mu$ s after 5 days only. Based on equations (5) and (6), $V_{s}$ and $G$ for the natural method and the acceleration method can be calculated and compared as shown in Figure 5(c). This reveals that $V_{s}$ and $G$ for the natural method seem to be equivalent to those for the acceleration method. However, the biocementation process time for the acceleration method is about 10 times faster than that for the natural method. This shows the advantage of using the self-developed urease enzymes. As a result, the biocemented sand by the natural method is not focused on in this study due to its costliness.

4.2. $\mathrm{NH}_{4}{ }^{+}-\mathrm{N}$ Production and Solution $\mathrm{pH}$ in Biocemented Sand. During biocementation, $\mathrm{NH}_{4}^{+}$concentration in principle increases due to decomposing $\mathrm{CO}\left(\mathrm{NH}_{2}\right)_{2}$ by (1) nitrification of microorganisms in BSR using the natural method, or (2) the ureolysis reaction of urease in BSR using the chemically enzymatic-induced method (or urease enzymatic acceleration method). The decomposition increases both the ammonification rate of biocemented sand and also its solution $\mathrm{pH}$ leading to the increase of $V_{s}$. Comparing the biocemented sand by the natural and the acceleration methods using the spectrophotometer, Figure 6 represents the change of $\mathrm{NH}_{4}{ }^{+}-\mathrm{N}$ production with treatment time (socalled ammonification rate) as well as the change of solution $\mathrm{pH}$ with treatment time. By considering Figures 6(a) and $6(\mathrm{~b})$, the $\mathrm{NH}_{4}{ }^{+}-\mathrm{N}$ production rate (ammonification rate) of the biocemented sand by the acceleration method is obviously higher than that by the natural method. The maximum ammonification rate of the biocemented sand by the acceleration method is equal to $2355 \mathrm{mg} \mathrm{N} \mathrm{L}^{-1} \mathrm{~d}^{-1}$ after 3 days only, while that by the natural method is equal to $451 \mathrm{mg} \mathrm{N} \mathrm{L}^{-1} \mathrm{~d}^{-1}$ after 40 days. Considering the biocemented sand by the acceleration method in Figure 6(b), the ammonification rate decreases from 4-day to 5-day treatment; however, $V_{s}$ continues to increase from 248.4 to $305.8 \mathrm{~m} \mathrm{~s}^{-1}$. This occurs because high solution $\mathrm{pH}$ (higher than 8 ) still continues to induce the precipitation of $\mathrm{CaCO}_{3}$ within voids of sand. This results in decreasing pore space of sand while increasing solid content in the biocemented sand and also results in increasing $V_{s}$ as well as enhancing its strength. Comparing Figures 6(a) and 6(b), the increase of the solution $\mathrm{pH}$ of the biocemented sand by the acceleration method is obviously higher than that by the natural method. In other words, the reaction time to reach the alkaline level as indicated by the solution $\mathrm{pH}$ of 8 occurred after 3 days for urease enzymatic acceleration method, while the other occurred after 20 days for the natural method. Moreover, the maximum solution $\mathrm{pH}$ of 8.2 by the acceleration method occurs within 3 days, whereas that by the natural method occurs within 40 days. This confirms that the ammonification rate by the acceleration method is better than that by the natural method. These implied that the urease activity of urea converting to ammonia by direct addition of urease enzymatic acceleration method was relatively higher than that of natural bacteria. Moreover, in our experiment, the water used for mixing the solution in the urease enzymatic acceleration method was distilled water. Thus, the urease activity of indigenous bacteria in the solution can be neglected.

4.3. Concentrations of $\mathrm{Ca}^{2+}$ Ions in Biocemented Sand. According to bender element test, Table 2 shows that the dry sand has $V_{s}$ of $133.4 \mathrm{~m} \mathrm{~s}^{-1}$ and $G$ of $26.1 \mathrm{MPa}$. By increasing the $\mathrm{Ca}^{2+}$ concentration, $V_{s}$ and $G$ tend to increase. The maximum value of $V_{s}$ and $G$ occurs at the $\mathrm{Ca}^{2+}$ concentration of $250 \mathrm{mM}$. In other words, $V_{s}$ and $G$ are lowest for 


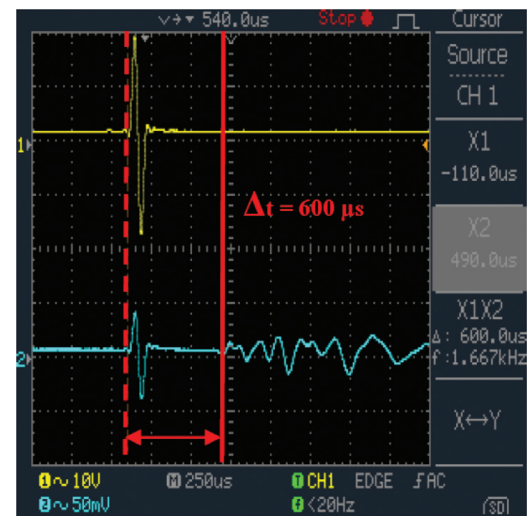

(a)

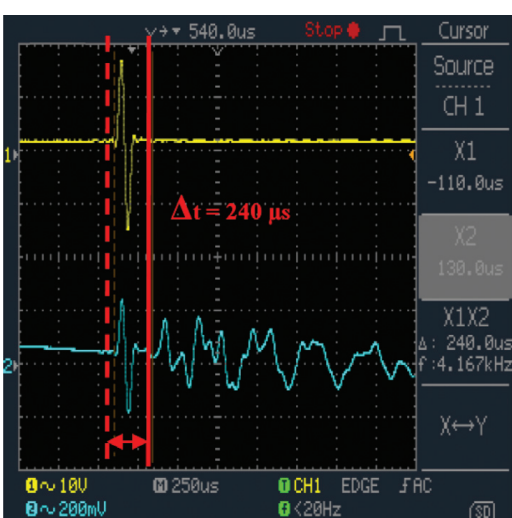

(b)

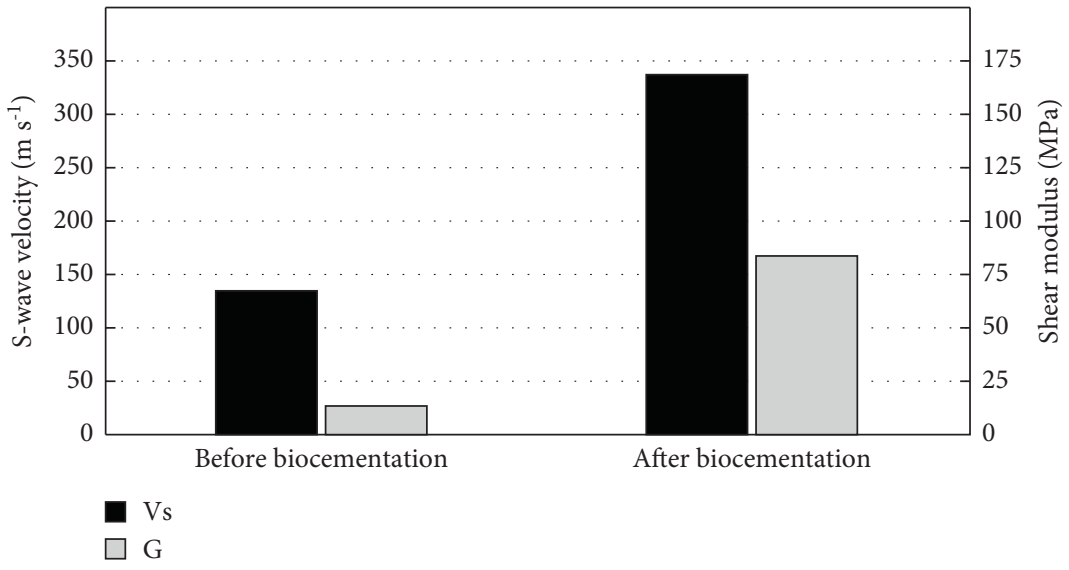

(c)

Figure 4: Bender element S-wave velocity: (a) untreated sand (before), (b) biocemented sand by the 50-day natural method (after), and (c) $V_{s}$ and $\mathrm{G}$ of untreated sand and biocemented sand by the 50 -day natural method.
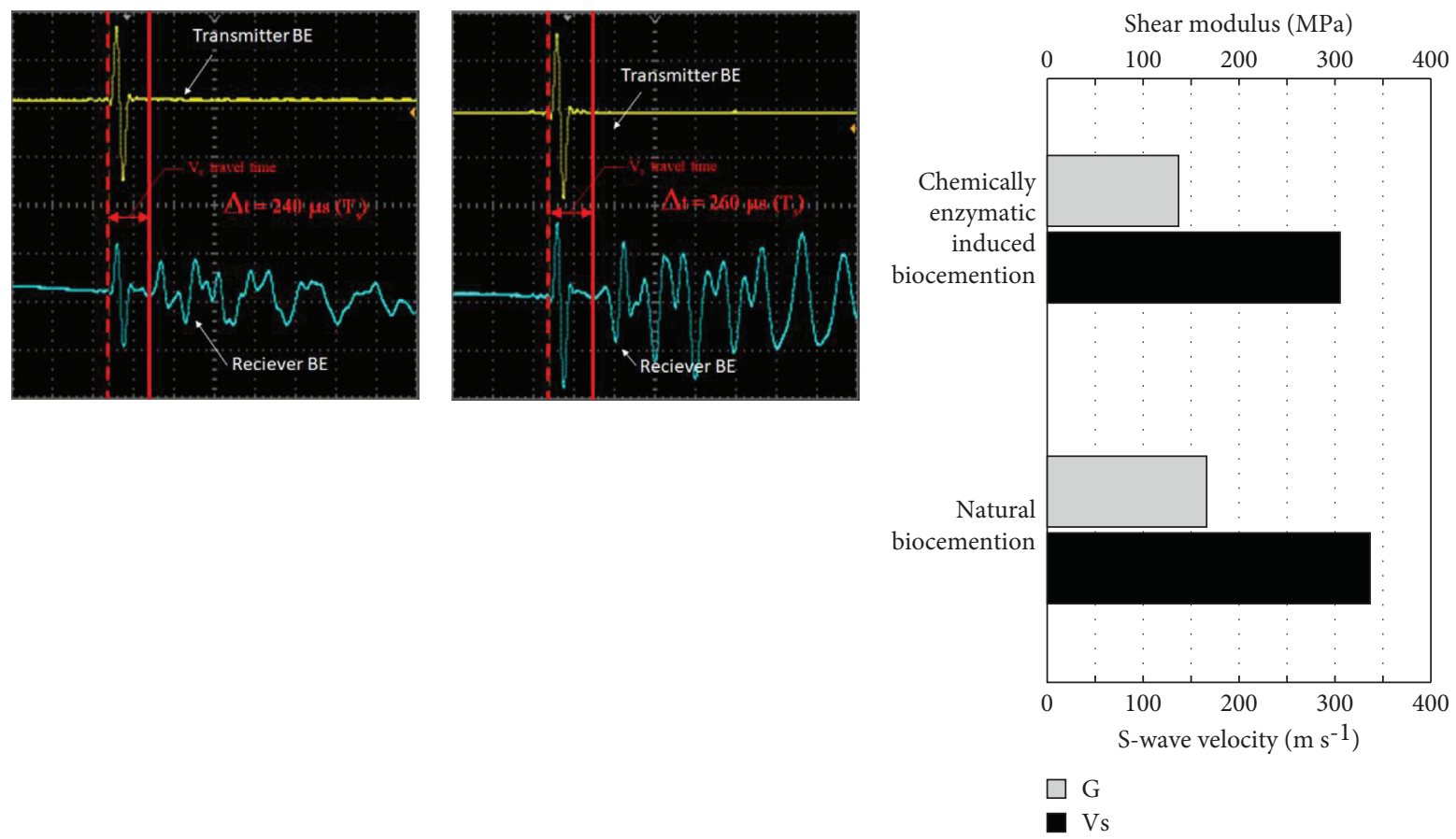

(a)

(b)

(c)

Figure 5: Bender element S-wave velocity through biocemented sand: (a) 50-day natural method, (b) 5-day chemically enzymatic-induced method using urease acceleration, and (c) $V_{s}$ and $\mathrm{G}$ by the 50-day natural method and 5-day chemically enzymatic-induced method using urease acceleration. 


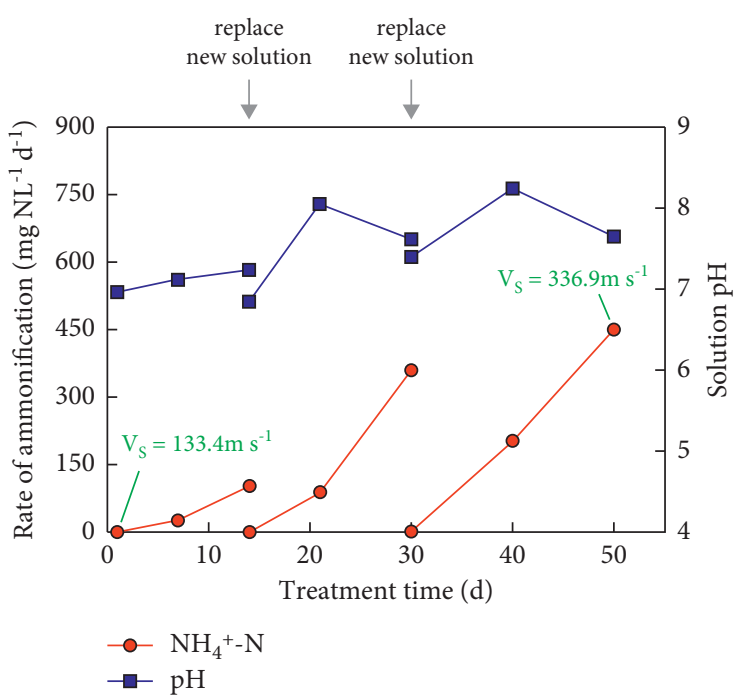

(a)

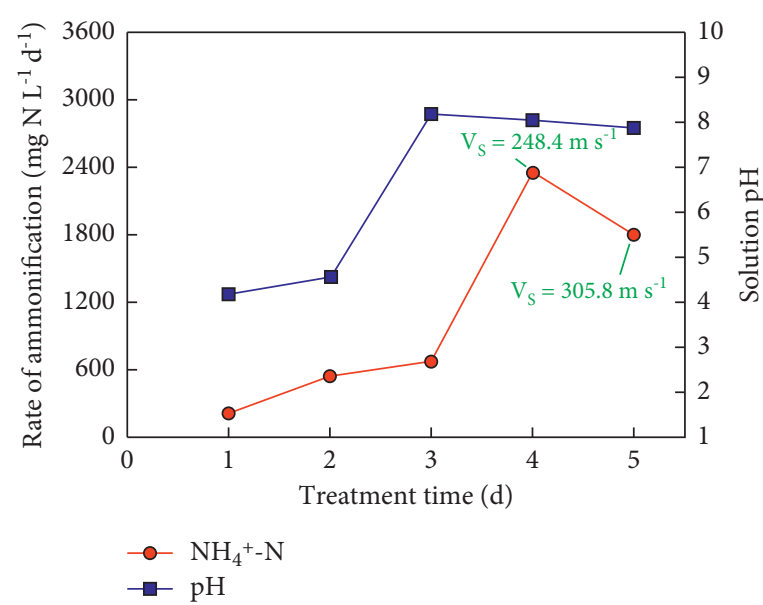

(b)

FiguRE 6: $\mathrm{NH}_{4}{ }^{+}$-N production rate (ammonification rate) and solution $\mathrm{pH}$ of biocemented sand: (a) 50-day natural method and (b) 5-day urease enzymatic acceleration method.

TABle 2: Effect of $\mathrm{Ca}^{2+}$ concentrations on $V_{s}$ and $G$ (by bender element tests), as well as $\mathrm{C}$ and $\phi$ (by direct shear tests).

\begin{tabular}{lcccccc}
\hline $\mathrm{Ca}^{2+}(\mathrm{mM})$ & $\mathrm{CO}\left(\mathrm{NH}_{2}\right)_{2}(\mathrm{mM})$ & Urease $(\%, \mathrm{v} / \mathrm{v})$ & $V_{s}\left(\mathrm{~m} \mathrm{~s}^{-1}\right)$ & $\mathrm{G}(\mathrm{MPa})$ & Cohesion, $\mathrm{C}\left(\mathrm{T} \mathrm{m}^{-2}\right)$ & Internal friction angle, $\phi($ degree $)$ \\
\hline 0 & 0 & 0 & 133.4 & 26.10 & 0.48 & 23 \\
50 & 250 & 20 & 193.9 & 55.24 & 0.89 & 14.8 \\
100 & 250 & 20 & 236.61 & 82.25 & 0.94 & 27.7 \\
250 & 250 & 20 & 305.77 & 137.37 & 1.59 & 32 \\
500 & 250 & 20 & 139.47 & 28.58 & 0.39 & 27.6 \\
\hline
\end{tabular}

the untreated sand, but they increase with biocementation. These results agree with the study of Duraisamy and Airey [21] who performed the bender element test mounted in a triaxial cell to relate the shear wave velocity to the strength of sandy soil. From their study, it was also found that the strength of sandy soil tended to increase with increasing $\mathrm{Ca}^{2+}$ concentration.

Other than the bender element test, the direct shear tests according to the ASTM D3080 were also performed to determine the cohesion and the friction angle of untreated and biocemented sand. For this, all sand samples were placed in a direct shear box, and their unit weight was controlled at $1470 \mathrm{~kg} \mathrm{~m}^{-3}$. The direct shear tests were applied to the untreated and biocemented sand with the normal stress of $4.19,6.99$, and $15.38 \mathrm{Tm}^{-2}$. With biocementation, both $\mathrm{C}$ and $\phi$ tend to increase as shown in Table 2. By further varying the concentration of $\mathrm{Ca}^{2+}$ ions, the optimum $\mathrm{Ca}^{2+}$ concentration for biocementation is found as $250 \mathrm{mM}$, providing the highest cohesion of $1.59 \mathrm{Tm}^{-2}$ as well as the highest internal friction angle of 32 degree. This tendency agrees with the test results of $V_{s}$ and $G$ by the real-time BE monitoring system, as shown in Table 2.

It is also of interest to observe that, at the $\mathrm{Ca}^{2+}$ concentration of $500 \mathrm{mM}$, a detrimental effect on the improvement of the biocemented sand is observed, as its properties are comparatively close to the properties of the untreated sand. This occurs because high concentration of
$\mathrm{Ca}^{2+}\left(\right.$ as $\left.\mathrm{CaCl}_{2}\right)$ results in high $\mathrm{Cl}^{-}$concentration in the solution. And $\mathrm{Cl}^{-}$ions possibly react with $\mathrm{H}^{+}$and $\mathrm{NH}_{4}^{+}$ions (see also equation (3)) in the solution to form $\mathrm{HCl}$ and $\mathrm{NH}_{4} \mathrm{Cl}$, respectively. This can lead to solution acidification rather than alkalinity (higher than 8 ). The acidification leads to the condition that the amount of $\mathrm{CO}_{3}^{2-}$ ions is not enough for $\mathrm{CaCO}_{3}$ precipitation in the biocemented sand. As a result, the optimum concentration of $\mathrm{Ca}^{2+}$ ions at $250 \mathrm{mM}$ was used throughout this study.

4.4. Morphology of Biocemented Sand. Figures 7 and 8 show the images from the scanning electron microscope (SEM) for the biocemented sand with $\mathrm{Ca}^{2+}$ of $250 \mathrm{mM}, \mathrm{CO}\left(\mathrm{NH}_{2}\right)_{2}$ of $250 \mathrm{mM}$, and urease of $20 \%$ by volume. Figures 7 (a) and 7(b) show the image with magnification by $100 \mathrm{x}$ and $500 \mathrm{x}$, respectively. Figure 7 (c) shows the arrow-marked image in Figure 7 (b) with magnification by $1000 x$. Figure $7(d)$ shows the circle-marked image in Figure 7(c) with magnification by $3000 x$, and it clearly indicates the precipitation of $\mathrm{CaCO}_{3}$ crystal. By further considering other images, Figure 8(a) depicts the 500x image, which shows the agglomeration of sand, while Figure 8(b) depicts the $1000 \mathrm{x}$ image, which confirms the occurrence of $\mathrm{CaCO}_{3}$ on the surface of sand. This reveals that $\mathrm{CaCO}_{3}$ fills into voids within sand and also coats on its surface. Moreover, $\mathrm{CaCO}_{3}$ not only agglomerates sand, but also improves its cohesion. It is also observed that 


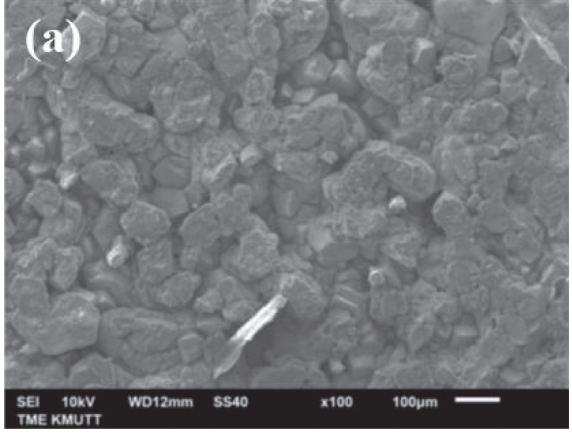

(a)

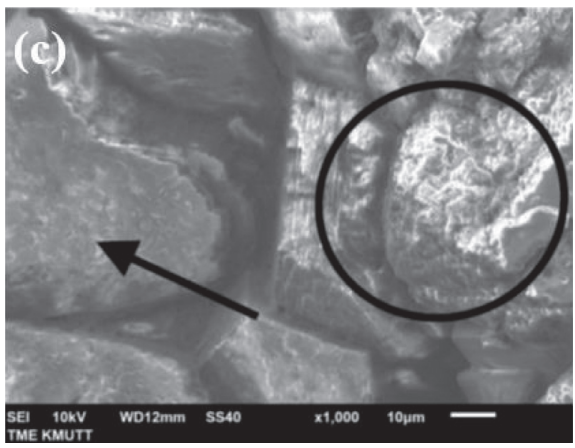

(c)

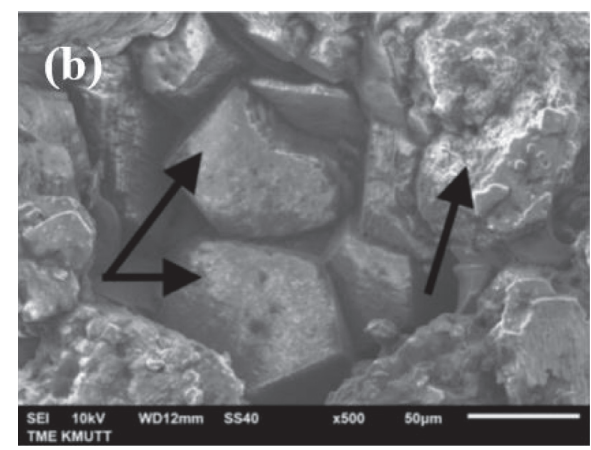

(b)

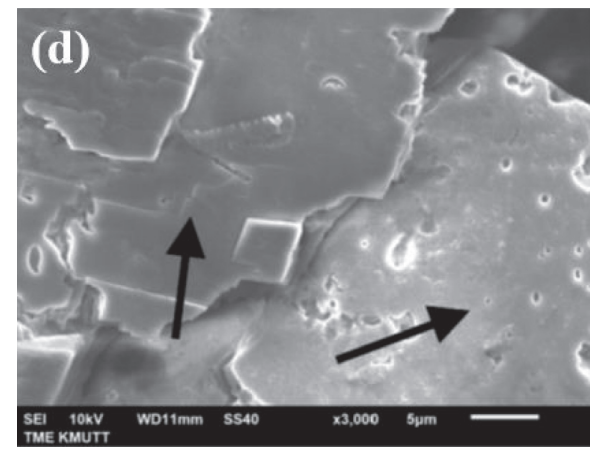

(d)

FiguRE 7: SEM images of precipitated $\mathrm{CaCO}_{3}$ crystal in biocemented sand by the urease enzymatic acceleration method: (a) 100x, (b) 500x, (c) $1000 \mathrm{x}$, and (d) 3000x.

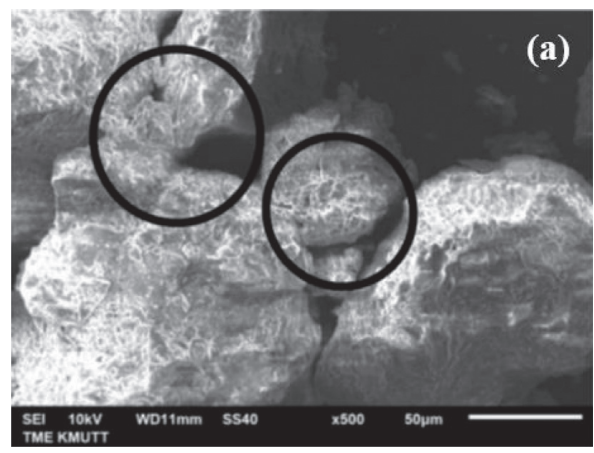

(a)

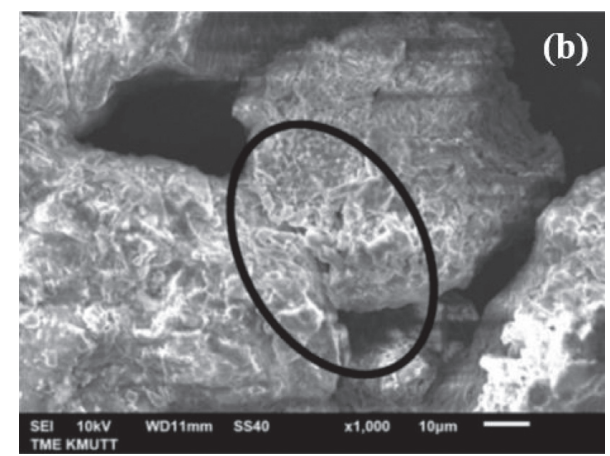

(b)

FIgure 8: SEM images of $\mathrm{CaCO}_{3}$ as sand binder in biocemented sand by the urease enzymatic acceleration method: (a) 500x and (b) 1000x.

the SEM result in Figures 7 and 8 indicated the occurrence of $\mathrm{CaCO}_{3}$ which is related to the alkalinity in the solution, leading to the confirmation of the reaction in equations (1)-(4).

4.5. X-Ray Diffractogram of Biocemented Sand. Using the X-ray diffractogram (XRD) analyses, Figure 9 compares typical sand (without biocementation) and the biocemented sand using $\mathrm{Ca}^{2+}$ of $250 \mathrm{mM}, \mathrm{CO}\left(\mathrm{NH}_{2}\right)_{2}$ of $250 \mathrm{mM}$, and urease of $20 \%$ by volume (v/v). A little difference in the pattern of XRD indicates that the biocementation process has a small impact on the chemical compositions of the biocemented sand, although significantly affects their physical strength (as indicated in Table 2). Moreover, the difference of the peaks probably occurs in the biocemented sand due to $\mathrm{CaCO}_{3}$ precipitation, which relies on the generation of $\mathrm{CO}_{3}{ }^{2-}$ and $\mathrm{OH}^{-}$as accelerated by urease enzymes. In the other words, the $\mathrm{CaCO}_{3}$ precipitation takes place due to the biological degradation and ureolytic reaction of $\mathrm{CO}\left(\mathrm{NH}_{2}\right)_{2}$ which increases the solution $\mathrm{pH}$ in the biocemented sand. This increase induces the alkalinity of the biocemented sand to be higher than 8 . At this alkalinity condition, the production rate of $\mathrm{NH}_{4}{ }^{+}-\mathrm{N}$ or the ammonification rate of the biocemented sand increases. 


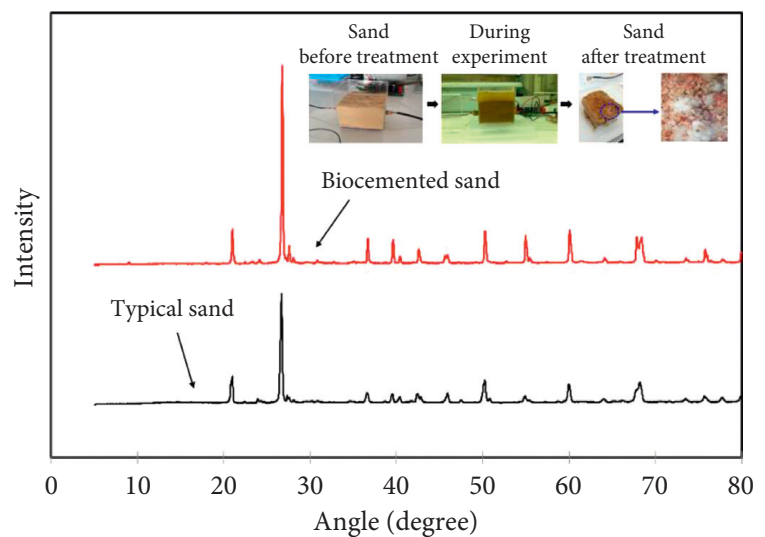

Figure 9: X-ray diffractogram of sand without and with biocementation by the urease enzymatic acceleration method (typical and biocemented sand samples, respectively).

\section{Conclusion}

In this study, the improvement of sandy soil properties by MICP-based biocementation with reaction accelerations using self-developed soybean urease enzymes is investigated. Various equipment was used, i.e., the self-developed realtime bender element monitoring system, the spectrophotometer and $\mathrm{pH}$ meter, the direct shear tests, and the XRD and SEM. In the experiment, the soybean urease enzymes of $20 \%$ by volume $(\mathrm{v} / \mathrm{v})$ to accelerate the MICP reaction to finish within 7 days were focused on, and also the concentration of $\mathrm{Ca}^{2+}$ ions as $\mathrm{CaCl}_{2}$ was varied at 50, 100, 250, and $500 \mathrm{mM}$ to investigate the optimum shear strength. From the study, it is found that

(1) With equivalent $\mathrm{S}$-wave velocity $\left(V_{s}\right)$ and initial shear modulus $(G)$, the treatment time of biocementation process in the acceleration method is about 10 times faster than that in the natural method. This shows the advantage of using the self-developed urease enzymes in the acceleration method.

(2) The $\mathrm{NH}_{4}{ }^{+}-\mathrm{N}$ production rate (or ammonification rate) and the solution $\mathrm{pH}$ in biocemented sand by 3 day acceleration method are relatively higher than those by 40 -day natural method. Despite the decrease of the ammonification rate from 4-day to 5day treatment, $V_{\mathrm{s}}$ of biocemented sand by the acceleration method continues to increase, because high solution $\mathrm{pH}$ (higher than 8) still induces the $\mathrm{CaCO}_{3}$ precipitation causing the decrease of voids within sand. This continues to enhance the strength of the biocemented sand.

(3) With increasing the concentrations of $\mathrm{Ca}^{2+}$ ions, both the cohesion $(\mathrm{C})$ and the internal friction angle $(\phi)$ tend to increase. The optimum concentration of $\mathrm{Ca}^{2+}$ ions for the highest value of $\mathrm{C}$ and $\phi$ is found at $250 \mathrm{mM}$ using soybean urease enzymes of $20 \%$ by volume. This optimum value was confirmed through both the direct shear tests and the real-time $\mathrm{BE}$ monitoring system.
(4) Using high concentration of $\mathrm{Ca}^{2+}$ (as $\mathrm{CaCl}_{2}$ ), a detrimental effect on the strength improvement of biocemented sand may occur, because high $\mathrm{Cl}^{-}$ions in the solution possibly react with $\mathrm{H}^{+}$and $\mathrm{NH}_{4}^{+}$ions to form $\mathrm{HCl}$ and $\mathrm{NH}_{4} \mathrm{Cl}$, respectively. This can lead to acidification rather than alkalinity (higher than 8). The acidification leads to the condition that the amount of $\mathrm{CO}_{3}^{2-}$ ions is not enough for $\mathrm{CaCO}_{3}$ precipitation in biocementation.

(5) The scanning electron microscope (SEM) images clearly reveal the precipitation of $\mathrm{CaCO}_{3}$ crystal. Moreover, $\mathrm{CaCO}_{3}$ not only fills into voids within sand, but also coats on its surface. These lead to the agglomeration of sand, as well as the improvement of the cohesion of sand.

(6) The X-ray diffractogram (XRD) analyses reveal that the biocementation process has a small impact on the chemical compositions of biocemented sand, although it significantly affects its physical strength. The peak values in $\mathrm{XRD}$ rely on $\mathrm{CaCO}_{3}$ precipitation. This precipitation results from the biological degradation and ureolytic reaction of $\mathrm{CO}\left(\mathrm{NH}_{2}\right)_{2}$, which increases the solution $\mathrm{pH}$ (higher than 8) and the ammonification rate of the biocemented sand.

(7) For further study, it is recommended that the bacterial genome should be determined for comparing its urease activity with other studies.

\section{Data Availability}

The test data used to support the findings of this study are available from the corresponding author upon request.

\section{Conflicts of Interest}

The authors declare that they have no conflicts of interest.

\section{Acknowledgments}

This research was funded by King Mongkut's University of Technology North Bangkok (contract no. KMUTNBBasicR-64-35).

\section{References}

[1] J. T. DeJong, B. M. Mortensen, B. C. Martinez, and D. C. Nelson, "Bio-mediated soil improvement," Ecological Engineering, vol. 36, no. 2, pp. 197-210, 2010.

[2] M. Umar, K. A. Kassim, and K. T. Ping Chiet, "Biological process of soil improvement in civil engineering: a review," Journal of Rock Mechanics and Geotechnical Engineering, vol. 8, no. 5, pp. 767-774, 2016.

[3] A. Petcherdchoo, "Sensitivity of service life extension and $\mathrm{CO}_{2}$ emission due to repairs by silane treatment applied on concrete structures under time-dependent chloride attack," Advances in Materials Science and Engineering, vol. 2018, Article ID 2793481, 10 pages, 2018.

[4] A. Petcherdchoo, "Probability-based sensitivity of service life of chloride-Attacked concrete structures with multiple cover 
concrete repairs," Advances in Civil Engineering, vol. 2018, Article ID 4525646, 17 pages, 2018.

[5] A. Petcherdchoo, T. Hongubon, N. Thanasisathit, K. Punthutaecha, and S.-H. Jang, "Effect of curing time on bond strength between reinforcement and fly-ash geopolymer concrete," Applied Science and Engineering Progress, vol. 13, no. 2, pp. 127-135, 2020.

[6] N. J. Jiang, C. S. Tang, T. Hata, B. Courcelles, O. Dawoud, and D. N. Singh, "Bio-mediated soil improvement: the way forward," Soil Use \& Management, vol. 36, no. 2, pp. 185-188, 2020.

[7] K. Piriyakul and J. Iamchaturapatr, "Biocementation through microbial calcium carbonate precipitation," Journal of Industrial Technology, vol. 9, pp. 195-218, 2013.

[8] V. Ivanov and J. Chu, "Applications of microorganisms to geotechnical engineering for bioclogging and biocementation of soil in situ," Reviews in Environmental Science and Biotechnology, vol. 7, no. 2, pp. 139-153, 2008.

[9] L. A. van Paassen, R. Ghose, T. J. M. van der Linden, W. R. L. van der Star, and M. C. M. van Loosdrecht, "Quantifying biomediated ground improvement by ureolysis: large-Scale biogrout experiment," Journal of Geotechnical and Geoenvironmental Engineering, vol. 136, no. 12, pp. 1721-1728, 2010.

[10] L. M. Lee, "Bio-mediated soil: a sustainable ground improvement technique," Jurnal Geoteknik HATTI, vol. IX, no. 1, pp. 30-39, 2014.

[11] A. Zamani and B. M. Montoya, "Undrained bhavior of silty soil improved with microbial induced cementation," in Proceedings of the 6th International Conference on Earthquake Geotechnical Engineering, Christchurch, New Zealand, November 2015.

[12] B. Li, "Geotechnical properties of biocement treated sand and clay," Doctoral thesis, Nanyang Technological University, Singapore, 2015.

[13] Y. Xiao, H. Chen, A. W. Stuedlein et al., "Restraint of particle breakage by biotreatment method," Journal of Geotechnical and Geoenvironmental Engineering, vol. 146, no. 11, 2020.

[14] V. Stabnikov, C. Jian, V. Ivanov, and Y. Li, "Halotolerant, alkaliphilic urease-producing bacteria from different climate zones and their application for biocementation of sand," World Journal of Microbiology and Biotechnology, vol. 29, no. 8, pp. 1453-1460, 2013.

[15] J. Iamchaturapatr and K. Piriyakul, "Effect of urease dosages in biocementation process for improving strength of sandy soil," Advanced Materials Research, vol. 931-932, pp. 698-702, 2014.

[16] L. Cheng, M. A. Shahin, and R. Cord-Ruwisch, "Bio-cementation of sandy soil using microbially induced carbonate precipitation for marine environments," Géotechnique, vol. 64, no. 12, pp. 1010-1013, 2014.

[17] J. P. S. F. Carmona, P. J. V. Oliveira, and L. J. L. Lemos, "Biostabilization of a sandy soil using enzymatic calcium carbonate precipitation," Procedia Engineering, vol. 143, pp. 1301-1308, 2016.

[18] X. Yu and Y. Gao, "Biocomposite cement-based mortar," Sustainable Construction and Building Materials, IntechOpen, London, UK, 2018.

[19] M.-J. Cui, H.-J. Lai, T. Hoang, and J. Chu, "One-phase-low$\mathrm{pH}$ enzyme induced carbonate precipitation (EICP) method for soil improvement," Acta Geotechnica, vol. 16, no. 2, pp. 481-489, 2021.

[20] N. Mohamed, N. Hafez, M. El-Mahillawy, and A. Sharaky, "Stabilization characteristics of different loose sandy soils using microbial-induced calcite precipitation," Walailak Journal of Science and Technology, vol. 18, no. 9, 2021.

[21] Y. Duraisamy and D. Airey, "Geomechanical behavior of biocemented sand for foundation works," Sandy Materials in Civil Engineering - Usage and Management, IntechOpen, London, UK, 2019.

[22] G. Ma, X. He, X. Jiang, H. Liu, J. Chu, and Y. Xiao, "Strength and permeability of bentonite-assisted biocemented coarse sand," Canadian Geotechnical Journal, vol. 58, 2020.

[23] L. Liu, H. Liu, Y. Xiao, J. Chu, P. Xiao, and Y. Wang, "Biocementation of calcareous sand using soluble calcium derived from calcareous sand," Bulletin of Engineering Geology and the Environment, vol. 77, no. 4, pp. 1781-1791, 2017.

[24] S.-G. Choi, S.-S. Park, S. Wu, and J. Chu, "Methods for calcium carbonate content measurement of biocemented soils," Journal of Materials in Civil Engineering, vol. 29, no. 11, 2017.

[25] L. Cheng, Y. Yang, and J. Chu, "In-situmicrobially induced $\mathrm{Ca} 2+$-alginate polymeric sealant for seepage control in porous materials," Microbial Biotechnology, vol. 12, no. 2, pp. 324-333, 2018.

[26] Y. Tang, G. Xu, Y. Yan et al., "Thermal cracking analysis of microbial cemented sand under various strains based on the DEM," Advances in Materials Science and Engineering, vol. 2018, Article ID 7528746, 15 pages, 2018.

[27] Z. Wang, N. Zhang, J. Ding, C. Lu, and Y. Jin, "Experimental study on wind erosion resistance and strength of sands treated with microbial-induced calcium carbonate precipitation," Advances in Materials Science and Engineering, vol. 2018, Article ID 3463298, 10 pages, 2018.

[28] Z. Wang, N. Zhang, F. Lin, J. Ding, and H. Yang, "Thermal conductivity of dry sands treated with microbial-induced calcium carbonate precipitation," Advances in Materials Science and Engineering, vol. 2019, Article ID 4562958, 8 pages, 2019.

[29] D. Yang, G. Xu, and Y. Duan, "Effect of particle size on mechanical property of bio-treated sand foundation," Applied Sciences, vol. 10, no. 22, p. 8294, 2020.

[30] M. G. Gomez, C. M. Anderson, C. M. R. Graddy, J. T. DeJong, D. C. Nelson, and T. R. Ginn, "Large-scale comparison of bioaugmentation and biostimulation approaches for biocementation of sands," Journal of Geotechnical and Geoenvironmental Engineering, vol. 143, 2016.

[31] C. Zeng, Y. Veenis, C. A. Hall et al., "Experimental and numerical analysis of a field trial application of microbially induced calcite precipitation for ground stabilization," Journal of Geotechnical and Geoenvironmental Engineering, vol. 147, 2021.

[32] C. Fang and V. Achal, "Biostimulation of calcite precipitation process by bacterial community in improving cement stabilized rammed earth as sustainable material," Applied Microbiology and Biotechnology, vol. 103, 2019.

[33] W. De Muynck, N. De Belie, and W. Verstraete, "Microbial carbonate precipitation in construction materials: a review," Ecological Engineering, vol. 36, no. 2, pp. 118-136, 2010.

[34] S. Castanier, G. Le Méteyer-Levrel, and L. Martire, "Bacterial roles in the precipitation of carbonate minerals,", in Microbial Sediments, R. E. Riding and S. M. Awramik, Eds., Springer, Heidelberg, Germany, 2000.

[35] F. Hammes and W. Verstraete*, "Key roles of $\mathrm{pH}$ and calcium metabolism in microbial carbonate precipitation," Reviews in Environmental Science and Biotechnology, vol. 1, no. 1, pp. 3-7, 2002. 
[36] V. S. Whiffin, J. W. M. Lambert, and C. C. D. VanRee, "Biogrout and biosealing - pore-space engineering with bacteria," Geo-Strata - Geo Institute of ASCE, vol. 5, no. 5, pp. 13-16, 2005.

[37] M. Nemati and G. Voordouw, "Modification of porous media permeability, using calcium carbonate produced enzymatically in situ," Enzyme and Microbial Technology, vol. 33, no. 5, pp. 635-642, 2003.

[38] J. T. DeJong, M. B. Fritzges, and K. Nüsslein, "Microbially induced cementation to control sand response to undrained shear," Journal of Geotechnical and Geoenvironmental Engineering, vol. 132, no. 11, pp. 1381-1392, 2006.

[39] V. S. Whiffin, L. A. van Paassen, and M. P. Harkes, "Microbial carbonate precipitation as a soil improvement technique," Geomicrobiology Journal, vol. 24, no. 5, pp. 417-423, 2007.

[40] K. Piriyakul, "A development of a bender element apparatus," The Journal of King Mongkut's University of Technology North Bangkok, vol. 20, no. 2, pp. 363-369, 2010.

[41] E.W. Rice, R.B. Baird, and A.D. Eaton, Standard Methods for the Examination of Water and Wastewater, American Public Health Association, American Water Work Association and Water Environment Federation, Washington, DC, USA. 